\title{
COMPARISON OF WEIGHT LOSS, FOOD CONSUMPTION AND FREQUENCY OF VOMITING AMONG ROUX-EN-Y GASTRIC BYPASS PATIENTS WITH OR WITHOUT CONSTRICTION RING
}

\author{
Comparação da perda de peso, consumo alimentar e frequência de vômitos entre pacientes do bypass gástrico em Y-de-Roux \\ com e sem colocação de anel de contenção
}

Silvia Leite FARIA, Orlando Pereira FARIA, Mariane de Almeida CARDEAL

From the Gastrocirurgia de Brasilia, Brasília, DF, Brasil (Gastrocirurgia Clinic of Brasília), Brasilia, DF, Brazil.

HEADINGS - Ring. Vomiting. Roux-en-Y gastric bypass.
ABSTRACT - Background: After Roux-en-Y gastric bypass to avoid rapid gastric emptying, dumping syndrome and regained weight due to possible dilation of the gastric pouch, was proposed to place a ring around the gastric pouch. Aim: To compare weight loss, consumption of macronutrients and the frequency of vomiting among patients who underwent Rouxen-Y gastric bypass with and without the placement of a constriction ring around the pouch. Method: A retrospective study, in which an analysis of medical records was carried out, collecting data of two groups of patients: those who underwent the operation with the placement of a constriction ring (Ring Group) and those who underwent without the placement of a ring (NoRing Group). The food intake data were analyzed using three 24-hour recalls collected randomly in postoperative nutritional accompaniment. Data on the percentage of excess weight loss and the occurrence of vomiting were collected using the weight corresponding to the most recent report at the time of data collection. Results: Medical records of 60 patients were analyzed: 30 from the Ring Group (women: 80\%) and 30 from the No-Ring Group (women: 87\%). The average time since the Ring Group underwent the operation was $88 \pm 17.50$ months, and for the No-Ring Group $51 \pm 15.3$ months. The percentage of excess weight loss did not differ between the groups. The consumption of protein $(\mathrm{g})$, protein/ $\mathrm{kg}$ of weight, \%protein and fiber $(\mathrm{g})$ were higher in the No-Ring Group. The consumption of lipids (g) was statistically higher in the Ring Group. The percentage of patients who never reported any occurrence was statistically higher in the No-Ring Group $(80 \%$ vs.46\%). The percentage who frequently reported the occurrence was statistically higher in the Ring Group (25\%vs.0\%). Conclusion: The placement of a ring seems to have no advantages in weight loss, favoring a lower intake of protein and fiber and a higher incidence of vomiting, factors that have definite influence in the health of the bariatric patient.

\author{
Correspondence: \\ Silvia Leite Faria \\ E-mail: silvialeitefaria@brturbo.com.br \\ Financial source: none \\ Conflicts of interest: none
}

Received for publication: 21/01/2014 Accepted for publication: 13/05/2014

DESCRTORES - Anel. Vômitos, Bypass gástrico em Y-de-Roux.
RESUMO - Racional: Após bypass gástrico em Y-de-Roux e a fim de evitar o rápido esvaziamento gástrico, amenizar a síndrome de dumping e evitar o reganho de peso devido à possível dilatação da anastomose gastrojejunal, foi idealizada a colocação de um anel ao redor do reservatório gástrico. Objetivo: Comparar a perda de peso, o consumo de macronutrientes e a frequência de vômitos entre pacientes que realizaram o bypass gástrico em Y-de-Roux com e sem a colocação do anel de contenção. Métodos: Estudo retrospectivo na análise de prontuários para a coleta dos dados de dois grupos de pacientes: os que realizaram o bypass gástrico em Y-de-Roux com a colocação do anel de contenção ao redor da bolsa gástrica (grupo com anel) e sem a colocação do anel (grupo sem anel). Os dados de consumo alimentar foram analisados através de três recordatórios de 24 horas coletados aleatoriamente nos atendimentos nutricionais do pós-operatório. Os dados quanto à porcentagem de perda do excesso de peso e ocorrência de vômitos foram coletados utilizando o peso e o relato mais recente em relação ao período da coleta. Resultados: Analisaram-se prontuários de 60 pacientes: 30 do grupo com anel e 30 do grupo sem anel. A média do tempo de operado do grupo com anel foi de $88 \pm 17,5$ meses, e do grupo sem anel $51 \pm 15,3$ meses. A porcentagem de perda do excesso de peso não diferiu entre os grupos. 0 consumo de proteína (g), proteína/kg de peso, \%proteína e fibras (g) foi estatisticamente superior no grupo sem anel. O consumo de lipídios (g) foi estatisticamente superior no grupo com anel. A porcentagem de pacientes que nunca relataram a ocorrência foi estatisticamente superior no grupo sem anel (80\%vs46\%). A porcentagem que frequentemente relataram a ocorrência foi superior no grupo com anel $(25 \%$ vs0\%) $(p<0.01)$. Conclusão: A colocação do anel de contenção parece não apresentar vantagens na perda de peso, podendo favorecer menor consumo de proteínas e fibras e maior ocorrência de vômitos, fatores de total influência para a saúde do paciente bariátrico.

\section{INTRODUCTION}

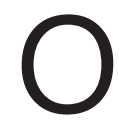
besity is often accompanied by various co-morbidities and poor quality of life. Bariatric surgery is the only treatment that promotes successful weight loss and long-term maintenance of weight loss $^{26}$. However, the standard of success after bariatric surgery is, besides excess weight loss, control of comorbidities arising from obesity as well as improvement in the quality of life of patients ${ }^{1}$.

However, the debate continues over what and how would be the best procedure to be followed ${ }^{1-3}$. Currently the most frequently performed procedure is Roux-en- $Y$ gastric bypass (RYGBP), which combines gastric restriction with intestinal malabsorption and 
causing significant weight loss and long-term maintenance of weight ${ }^{26}$. As part of this procedure, the pylorus is not included in the new gastric pouch. Accordingly, Fobi et al ${ }^{14-16}$ initiated description of alternative methods to prevent rapid gastric emptying, alleviate dumping syndrome, alleviate and avoid weight regain due to the possible dilatation of the gastro-jejunal anastomosis ${ }^{3}$. Such methods include placing a ring around the gastric pouch, giving rise to the so-called "banded" RYGBP.

However, some studies have shown decreased quality of life due to the reduced diameter that some rings can cause at the base of the gastric pouch provoking frequent vomiting ${ }^{1}$ and intolerance to some foods ${ }^{7}$ without showing significant differences in weight loss nor in resolution of comorbidades ${ }^{2}$. Some patients require the removal of the ring years after surgery, with immediate resolution of symptoms ${ }^{24}$. There is still no consensus on the need of placing a ring during $\mathrm{RYGBP}^{23}$ and studies monitoring the results with and without the placement of the ring are few and far between ${ }^{3}$.

Thus, the aim of this study was to compare weight loss, consumption of macronutrients (carbohydrates, protein and lipids) and frequency of vomiting among patients who underwent RYGBP with and without the placement of the constrictive ring around the gastric pouch.

\section{METHODS}

This was a retrospective study in which medical records from the Gastrocirurgia Clinic of Brasília, in Brasília, DF, Brazil, were analyzed. The objective was to compare data from two different groups of patients: those who underwent RYGBP with the placement of the constrictive ring around the gastric pouch (group with a ring) and those who underwent the same procedure without placement of the ring (group without a ring). Inclusion criteria were: availability of data on weight, food consumption and prevalence of vomiting during a period of one year or more after surgery; and having been operated on by the same surgical team. The standard ring used was one of silicone, $6.9 \mathrm{~cm}$ in length.

Food consumption data were collected using three random 24-hour recalls registered during postoperative nutritional care sessions at the end of the first year after the operation. The Diet Win $\AA$ program was used to calculate these data. The time since operation was considered that relative to the last nutritional consultation. Data on percentage of excess weight loss and the occurrence of vomiting were collected using the weight and the registers of this same session. Excess weight loss was calculated based on ideal body weight as established by tables produced by the Metropolitan Life Insurance Co, USA ${ }^{19}$.

The register of the occurrence of vomiting was based on the following parameters according to the frequency of the individual patient: never, rarely, occasional, monthly, once weekly, twice or more times per week. Accordingly, for purposes of analysis, the frequency was divided into: never, rarely, occasionally and frequently. Thus, the term "frequently" included patients who reported vomiting monthly, weekly and twice or more times per week.

To compare the mean values of variables between the groups with and without a ring, Student t tests and the nonparametric Mann-Whitney tests were used. To compare the frequency of vomiting between groups, the chi-square test was used.

RESULTS

There were 60 patients included in this study, 30 in the group with a ring (men: $20 \%$, women: $80 \%$ ) and 30 in the group without a ring (men: $13 \%$, women: $87 \%$ ). The mean time since operation for the group with a ring was $87.83 \pm 17.50$ months, and for the group without a ring, 50.69 \pm 15.29 months. Excess weight loss did not differ between groups. The consumption of protein (g), protein $/ \mathrm{kg}$ of body weight, \% of protein relative to the total energy value and fibers $(\mathrm{g})$ was higher in the group without a ring $(p=0.028 ; p=0.025 ; p<0.01$ and $p<0.01$, respectively). Fat intake (g) and \% of lipids in relation to total energy intake was higher in the group with a ring $(p=0.01$ and $p<0.01$, respectively) (Table 1 ).

The frequency of vomiting differed significantly between the groups $(p<0.01)$ since the percentage of patients who never reported the occurrence was statistically higher in the group without a ring (80\%vs46\%). The percentage who reported frequent occurrence was statistically higher in the group with a ring (25\%vs0\%) (Table 2 ).

TABLE 1 - Comparison of data on food consumption and percentage of excess weight loss between the groups with and without a constrictive ring

\begin{tabular}{|l|c|c|c|}
\hline & With ring & Without ring & \\
\hline Variable & Mean \pm SD & Mean \pm SD & p $^{*}$ \\
\hline PEWL* & $61.53 \pm 28.80$ & $65.42 \pm 16.56$ & 0.28 \\
\hline CHO (g)* & $112.38 \pm 42.35$ & $99.55 \pm 33.47$ & 0.10 \\
\hline PTN $(g)^{\#}$ & $59.62 \pm 15.88$ & $69.78 \pm 19.03$ & 0.03 \\
\hline LIP $(g)^{*}$ & $38.58 \pm 14.26$ & $30.79 \pm 15.23$ & 0.01 \\
\hline Fibers*(g) & $6.30 \pm 5.31$ & $9.10 \pm 3.51$ & $<0.01$ \\
\hline PTN/Kg\# & $0.73 \pm 0.27$ & $0.89 \pm 0.26$ & 0.02 \\
\hline TEV $(k c a l)$ & $1035.21 \pm 312.53$ & $954.44 \pm 246.29$ & 0.27 \\
\hline CHO (\%) & $42.75 \pm 7.95$ & $42.15 \pm 9.16$ & 0.78 \\
\hline PTN $(\%)^{\#}$ & $24.11 \pm 6.48$ & $29.61 \pm 5.33$ & $<0.01$ \\
\hline LIP $(\%)^{\#}$ & $33.14 \pm 6.07$ & $28.24 \pm 7.01$ & $<0.01$ \\
\hline
\end{tabular}

* $\mathrm{p}$ - value calculated based on the nonparametric Mann-Whitney test; ${ }^{*} \mathrm{p}$ - valor calculated based on Student's t-test; $S D=$ standard deviation; $P E W L=$ percentage of excess weight loss; $\mathrm{CHO}=$ carbohydrate; $\mathrm{PTN}=$ protein; $\mathrm{LIP}=$ lipids; $\mathrm{TEV}=$ total energy value.

TABLE 2 - Comparison of the frequency of vomiting among the groups with and without a ring

\begin{tabular}{|c|c|c|c|c|}
\hline & Never (\%) & Rarely (\%) & Occasionally (\%) & Frequently (\%) \\
\hline With a ring & 46.43 & 21.43 & 7.14 & 25.00 \\
\hline Without a ring & 80.00 & 20.00 & 0.00 & 0.00 \\
\hline
\end{tabular}

\section{DISCUSSION}

One factor that optimizes the effects of satiety after RYGBP is the constriction made in the distal part of the gastric pouch, which causes a delay in gastric emptying and consequent decrease in food intake. One of the ways that some surgeons achieve this goal is by placing a ring around the gastric pouch ${ }^{5,14}$. Fobi et al. ${ }^{14,15,16}$ pioneered the use of constrictive rings in gastric bypass procedures, placing them near the gastro-jejunal anastomosis.

In this study, no difference in weight loss between patients operated with and without the placement of the ring was found. A similar result was observed by Arceo-olaiz et al $(2008)^{2}$, in a study of 60 RYGBP patients with and without a constrictive ring of $6.5 \mathrm{~cm}$ in length, made of polypropylene. In this study, excess weight loss did not differ between the groups after 6,12 and 24 months postoperatively.

These results lead to reflection on other factors that influence postoperative weight loss. Eating habits ${ }^{9,10}$, physical activity and changes in hormone and energy metabolism resulting from the operação ${ }^{11,12}$, for example, seem to be great predictors of postoperative weight loss. Furthermore, the inclusion of a multidisciplinary team approach in bariatric surgery programs has improved weight loss and patient adherence to treatment, regardless of the presence of a constrictive ring. Besides this, ethnic and cultural 
characteristics may play a role in the success of surgery ${ }^{2}$.

Awad (2012) et al ${ }^{3}$ studied weight loss and quality of life of patients with and without a constrictive ring, $6.5 \mathrm{~cm}$ in length made of polypropylene. Excess weight loss up to 24 months postoperatively did not differ between the groups, but from 36 months to ten years after their operation, the group with a ring showed significantly greater weight loss. Despite this, excess weight loss in the group without a ring continued, from 36 months postoperative, at around $60 \%$ which is still considered to be a successful postoperative outcome, showing long-term weight loss maintenance even without placing a ring.

Stubbs et al. (2006) ${ }^{23}$ believe that the decision on the use of a ring is essentially based on the balance between the weight loss maintenance and quality of diet. In the study by Awad et al (2012) ${ }^{3}$ the group with a ring had greater difficulty in eating. It is known that the quality and variety of food decreases in proportion to the length of the ring ${ }^{25}$. In this study, similar results could be seen as in the case of protein and fiber consumption which was significantly lower, with significantly higher consumption of lipids in the group with a ring. Stubbs et al. (2006) ${ }^{23}$ observed that, indeed, meat consumption becomes less frequent as the ring length is decreased.

It is known that the quality of food has great influence on the quality of weight loss after RYGBP9,10. The study by Awad et al (2012) ${ }^{3}$, despite having observed long-term parameters and having found greater weight loss in patients with a ring, did not measure body composition in order to assess whether such weight loss was predominantly in the form fat, as is desired.

In this study, it was observed that the group with a ring had a average protein intake (in grams) below the lower recommended limit for bariatric patients $(60 \mathrm{~g})^{17}$. An inadequate protein intake can provoke greater loss of lean mass and still deprive the patient of a number of nutrients essential to health ${ }^{13}$. Thus, one cannot conclude as being positive the greater weight loss observed in the study group with a ring in the study of Awad et al. (2012) ${ }^{3}$ base exclusively on data presented in the study. In order to conclude that such weight loss was of good quality and that the patient's health was preserved, biochemical parameters and body composition should have been analyzed.

Fobi et al (1998) ${ }^{14}$ supported placing the constrictive ring around the gastric pouch, arguing that it is able to contain future expansion of a sutured stoma, which could result in increased volume of food intake and resultant weight regain if it were to be greater than $18 \mathrm{~mm}$. However, weight regain seems to have varied causes that go beyond a patient's simple ability to eat larger volumes. One possible cause, as shown by the authors of the present study in 2009 is the lower energy expenditure that such patients may present $^{11}$, and furthermore, specific eating habits, such as excessive consumption of caloric liquids, especially alcoholic beverages and the development of binge eating habits ${ }^{10}$ which can also impair weight loss after RYGBP.

The placement of a ring in order to maintain the size of the gastric pouch is still used by some surgeons in weight loss operations. Polypropylene, double knit, heavy sutures, Silastic ${ }^{\circledR}$, Dacron $\AA$ and Gore-Tex $\AA$ are some of the materials utilized ${ }^{5,14}$; however, none has been shown to immune to complications. Tadeucci et al. $(2008)^{25}$ believe that complications associated with a ring may outweigh its benefit. Complications such as band erosion, nausea vomiting, malnutrition and dysphagia for solids and liquids can occur ${ }^{24}$. Thus, most RYGBP surgeons now opt not to use a ring 22

Although it can occur, the development of vomiting after RYGBP is not common². Nevertheless, it can reach a frequency of $68.8 \%^{7,14}$. Most causes of vomiting due to stenosis of the anastomosis ${ }^{15}$ that can occur depending on the placement of the ring.

Since the ring showed no indication of having caused any difference in weight loss in this study, the group of patients with a ring showed significantly higher levels of frequent vomiting. Some other studies have reported the occurrence of vomiting related to a constrictive ring ${ }^{1,2}$. This study finds that one fourth of the patients with a ring reported the occurrence of vomiting as being frequent. Reports of its frequency show happen monthly, once/ twice a week or even more. Arasaki et al.(2005) ${ }^{1}$ consider chronic "vomiters" after bariatric surgery as those vomiting more than ten times a month. Others consider that the classification should be given to those who vomit more than three times per week ${ }^{2}$. Thus, not all patients who reported their vomiting as being frequent in this study can be considered chronic. Unfortunately, there are no data available here on the nutritional status of these patients. However, it is known that a register of "frequent" is important information, since vomit have serious concern when it become chronic provoking malnutrition ${ }^{8}$.

Another factor to consider is the length of the ring to be placed. The high prevalence of vomiting observed as a function of the ring is due to the reduced flow of food it causes. Arasaki et al. (2005) ${ }^{1}$ compared two groups of RYGBP patients: one of patients who received a ring $6.2 \mathrm{~cm}$ in length and another with $7.7 \mathrm{~cm}$ which allowed $100 \%$ flow of food through the gastric outlet. The chance of becoming chronic regurgitants was 4.5 times greater in the group with the shorter length than the other. Significant higher prevalence of chronic vomiting was seen among shorter rings ( $23 \%$ vs $8 \%$ ). The same was observed by Stubbs et al. $(2006)^{23}$, wherein the frequency of regurgitation was also higher in patients with $5.5 \mathrm{~cm}$ ring, compared with those of $6.5 \mathrm{~cm}$. These results show that excessive restriction of output of the gastric pouch can worsen the quality of life of patients and, without proper treatment, may increase chances of nutritional risk, which in turn, may lead to other serious complications, such as acute neuropathy ${ }^{6}$.

The initial recommendation of Fobi et al. ${ }^{14-16}$ was to place ring of $5.5 \mathrm{~cm}$ long. However, this size provoked a high removal rate (20\% of patients), which made him to change his recommendation for larger ring length, 6-6.5 cm in circumference. The ring size used in this study was even higher $-6.9 \mathrm{~cm}$ long - but this did not prevent the onset of complications, such as vomiting and food intake difficulties for the group with ring.

Treatment for vomiting after bariatric surgery usually consists of nutritional re-education, use of prokinetics and psychological support. In failure, the symptoms are interrupted only by removing the ring ${ }^{1,7,14,25}$. Laparoscopic removal is feasible and safe, with immediate and complete resolution of symptoms, and rapid recovery ${ }^{24,25}$. In addition, laparoscopic surgery placing constrictive ring is more expensive, since it represents a longer procedure with higher cost, worsening even more the cost-benefit of placing a ring during RYGBP.

This study has some limitations. Some authors suggest other hypotheses to explain the occurrence of vomiting after RYGBP; among them, the hypotony of the lower esophageal sphincter ${ }^{1}$, psychiatric diseases ${ }^{21}$, nutritional disabilities ${ }^{18}$, ingestion of large volumes of food ${ }^{4}$, insufficient chewing and drinking fluids during meals $\mathbf{s}^{5,20}$. These parameters were not examined in this study and may act as results confounders. Thus, medium and more long-term data, collected under better controlled conditions, comparing patients weight loss, body composition and other parameters that assess their health and quality of life with and without ring, are needed to draw meaningful conclusions in this regard. 
CONCLUSION

The placement of a constrictive ring during RYGBP does not offer advantages in weight loss and provokes lower consumption of protein and fibers with a higher incidence of vomiting. These factors negatively influence the quality of weight loss, the quality of life and the maintenance of health of the bariatric patient.

\section{REFERENCES}

1. Arasaki CH, Del Grande JC, Yanagita ET, Alves AK, Oliveira DR. Incidence of regurgitation after the banded gastric bypass. Obes Surg. 2005 Nov-Dec;15(10):1408-17.

2. Arceo-Olaiz R, España-Gómez MN, Montalvo-Hernández J, Velázquez-Fernández D, Pantoja JP, Herrera MF. Maximal weight loss after banded and unbanded laparoscopic Roux-en-Y gastric bypass: arandomized controlled trial. Surg Obes Relat Dis. 2008 Jul-Aug;4(4):507-11. Epub 2008 Jan 28.

3. Awad W, Garay A, Martínez C. Ten years experience of banded gastric bypass: does it make a difference? Obes Surg. 2012 Feb;22(2):271-8.

4. Becker DA, Balcer LJ, Galetta SL. The Neurological Complications of Nutritional Deficiency following Bariatric Surgery. J Obes. 2012;2012:608534. Epub 2012 Jun 13.

5. Brolin R. Gastric bypass. Surg Clin North Am 2001;81:1077-95.

6. Capella RF, Capella JF, Mandec H et al. Vertical banded gastroplasty - gastric bypass: Preliminary report. Obes Surg 1991; 1: 389-95.

7. Chang CG, Adams-Huet B, David A et al. Acute postgastric reduction surgery (APGARS) neuropathy. Obes Surg 2004; 14: 182-9.

8. Crampton NA, Izvornikov V, Stubbs RS. Silastic ring gastric bypass: a comparison of two ring sizes: a preliminary report. Obes Surg 1997; 7: 495-9.

9. Faintuch J, Matsuda M, Cruz MELF et al. Severe protein- calorie malnutrition after bariatric procedures. Obes Surg 2004; 14: 175-81.

10. Faria SL, Faria OP, Buffington C, de Almeida Cardeal M, Ito MK. Bariatric Protein Intake and Bariatric Surgery Patients: A Review. Obes Surg. 2011;21(11): 1798-1805.

11. Faria SL, Faria OP, Lopes TC, Galvão MV, de Oliveira Kelly E, Ito MK. Relation between carbohydrate intake and weight loss after bariatric surgery. Obes Surg. 2008;19(6):708-16.

12. Faria SL, Faria OP, Buffington C, de Almeida Cardeal M, Rodrigues de Gouvêa $\mathrm{H}$. Energy expenditure before and after Roux-en-Y gastric bypass. Obes Surg Epub 2012 May 18.

13. Faria SL, Faria OP, de Almeida Cardeal M, Gouvêa HR, Buffington C. Surg Obes Relat Dis. Diet-induced thermogenesis and respiratory quotient after Roux-en-Y gastric bypass. 2012 Jul 23. [Epub ahead of print]
14. Faria SL, Kelly E, Faria OP. Energy expenditure and weight regain in patients submitted to Roux-en-Y gastric bypass. Obes Surg. 2009;19:856-9.

15. Faria SL, Kelly EO, Faria OP, Ito, MK. Snack-eating patients experience lesser weight loss after Roux-en-Y gastric bypass surgery. Obes Surg. 2009;19(9):1293-6.

16. Flanagan $L J$ r. Understanding the function of the small gastric pouch. In: Deitel M, Cowan GSM Jr, eds. Update: Surgery for the Morbidly Obese Patient. Toronto: FD-Communications 2000: 147-60.

17. Fobi MAL, Lee $H$. The surgical technique of the Fobipouch operation for obesity (The transected Silastic $₫$ vertical gastric bypass). Obes Surg 1998; 8: 283-8.

18. Fobi MAL, Lee $\mathrm{H}$, Holness $\mathrm{R}$ et al. Gastric bypass operation for obesity. World J Surg 1998; 22: 925-35.

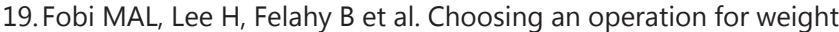
control, and the transected banded gastric bypass. Obes Surg 2005; 15: 114-21.

20. Heber D, Greenway FL, Kaplan LM, et al. Endocrine and nutritional management of the post-bariatric surgery patient: na OBES SURG Endocrine Society Clinical Practice Guideline. J Clin Endocrinol Metab. 2010;95(11):4823-43.

21. Kriwanek S, Blauensteiner W, Lebisch E et al. Dietary changes after vertical banded gastroplasty. Obes Surg 2000; 10: 37-40.

22. Metropolitan Life Foundation. Metropolitan height and weight tables. Metropolitan Life Foundation, Statistical Bulletin 1983;64 (1):2-9.

23. Segal A, Kussunoki DK, Larino MA. Post-surgical refusal to eat: anorexia nervosa, bulimia nervosa or a new eating disorder? A case series. Obes Surg 2004; 14: 353-60.

24. Shai I, Henkin Y, Weitzman S et al. Determinants of long-term satisfaction after vertical banded gastroplasty. Obes Surg 2003; 13: 269-74.

25. Stubbs RS, O'brien I, Jurikova L. What ring size should be used in association with vertical gastric bypass?Obes Surg. 2006 Oct;16(10):1298-303.

26. Swain JM, Scott P, Nesset E, Sarr MG. All strictures are not alike: laparoscopic removal of nonadjustable Silastic bands after banded Roux-en-Y gastric bypass.Surg Obes Relat Dis. 2012 MarApr;8(2):190-3. Epub 2010 Sep 22.

27. Taddeucci RJ, Madan AK, Ternovits CA, Tichansky DS. Laparoscopic re-operations for band removal after open banded gastric bypass. Obes Surg. 2007 Jan;17(1):35-8.

28. Papakonstantinou A, Alfaras $P$, Komessidou V et al.Gastrointestinal complications after vertical banded gastroplasty. Obes Surg 1998; 8: 215-7.

29. Valezi AC, Junior JM, de Menezes MA. Weight loss outcome after silastic ring Roux-en-Y gastric bypass: 8 years of follow-up. Obes Surg. 2010;20:1491-5. 